\title{
The Spiritual Communication: Phenomenological Study on the Urantia Community in Indonesia
}

\author{
Betty Tresnawaty \\ UIN Sunan Gunung Djati Bandung \\ Bandung, Indonesia \\ betty.tresnawaty@uinsgd.ac.id
}

\begin{abstract}
The Urantia Community consists of people with the same interest in spiritual values taught in The Urantia Book, a book that taught the origins of the universe, the history of the earth, values of life, philosophy, and spiritual. The community has existed since the 1950s in the United States and has expanded globally, including in Indonesia. As in the global context, the Indonesian Urantia Community shows harmony despite the wide diversity of backgrounds, including the different religious background. One of the interesting facts about this community is the spiritual growth among its members which implied to the improvement of their religious belief. That uniqueness has led me to examine the communication experience among the Urantia community in. The aims of this study are to identify, analyze, and explore more deeply about the interaction among Urantia Community members in Indonesia. By using interpretiveconstructivist paradigm with the qualitative approach and phenomenological methods, theories and concepts that used in this study among others Theory of Social Construction of Reality of Peter Berger and Luckmann and the Concept of Motive from Schultz. The results of this study have shown the interaction among members of this community led to a new understanding of the concept of spiritual communication, that is the taste value in the process of group communication, that in this case Indonesian Urantia Community.
\end{abstract}

Keywords-Communication experience;

Spiritual communication; Interaction.

\section{INTRODUCTION}

Communication from the sociological perspective is the interaction, so in here how the Urantia community members interact and communicate. This does not mean that all members should have exactly the same goal to become a member of the group. But in general, there should be a similar reason for the individual to interact. (DeVito, 1997: 303).

The Urantia community is the people who study and apply the content of the Urantia book spread out in several cities in Indonesia. They are united by a common interest, which is reading a book Urantia. They regularly gather once a week in Jakarta to discuss, share experiences, and perform other activities related to Urantia book. The Urantia book reader or "Urantia Readers" in more than 26 countries around the world, including in Indonesia. In Indonesia alone an emerging community of Urantia book reader is about 2002 (based on prestudy interview early 2013), but this book has been published since 1955 and began writing the 1933 Chicago United States.
So the existence of Urantia community in Indonesia is still fairly new, therefore there was wonder if there are many people who find it strange to hear the word "Urantia".

The word "Urantia" means the planet Earth. The Urantia Book speaks of the deepest desires of the human spiritual and convincing for those intellectual, fully integrating religion, philosophy and modern science through the development of spiritual growth and understanding of the universe that is commensurate with the level of human intellect and cultural development. The book opens up new vistas of time and eternity as well as new concepts of human travel that has always increased in the search for God Almighty. The book is composed of 196 documents/papers gives new record, extensive and structured on the origin, history and purpose of human life and the stages of human life to the afterlife after his physical death. As time goes by, the more members of the forum or group of people who study this Urantia book. The amount is up to now scattered in various countries including Indonesia.

Pierre Hadot (1995) Spiritual defines as "a whole way of being" existential unity of intellect, emotions, and psyche, and spiritual practice as a process of self-transformation and reorientation of this existential unity. Spirit indicates something more comprehensive than the psyche: digging spiritual, someone exposing himself to something beyond the psychological unity which we refer to it as a personal self (Roberts, 2002: 25). Spiritual is different with the supernatural, these two words are often same interpreted so sometimes there is not infrequently a shaman called spiritual advisor. Though based on personal experience, that the supernatural are things beyond human thought associated with mystical supernatural. While spiritually related to the individual that is personal.

According to Berger and Luckmann man will seek the knowledge that the phenomenon is real and has a special nature in everyday life. Furthermore, Berger suggests the reality of everyday life has dimensions of subjective and objective (Berger and Luckmann, 1966). When linked with this research it can be assumed that the Urantia community can form an understanding of the social reality according to what they perceive as the real thing. Berger mentioned that the society as a product of man and man as a product of society.

A Constructivist research does not come from a theory because it is not to test the theory, but in this case the need to examine the theories and concepts as well as previous research 
to understand both the theme and the research findings. Theoretical foundation used to analyze this research is, phenomenology theory and the theory of Social Construction of Reality. Phenomenology is the science of the phenomenon which is distinguished from something that has become and classifying phenomena. In other words, phenomenology study the phenomenon that appears in front of us, and how appearance. Phenomenology refers to all the views of social science that considers the human consciousness and the meaning of subjectivity as a focus for understanding social action.

The Schulz thought with a diverse background gives its own style in the tradition of phenomenology as a science study of communication. Although Weber influence is strong but Schulz also criticized Weber's thoughts. Schulz background in philosophy, music, sociology and other social sciences make phenomenological tradition becomes deeper and more comprehensive. Schulz made a tradition of phenomenology in social science especially study of science communication becomes clearer and easier to understand the applicability than Husserl rather abstract thinking. Husserl more looking in terms of transcendental phenomenology while Schulz more sociological implications. In addition Schulz explains not only the social world, but also explain the various concepts of science and theoretical models of reality, especially the reality of the everyday world that has properties intersubjective (the life world).

Theory of Social Construction of Reality, This theory is a social commentary on the fact that I try to interpret from Littlejohn book more or less revealed that the theory of Social Construction of Reality (Social Construction of Reality) was introduced by Peter Berger and Thomas Luckmann. This theory refers to the process by which people together to build their understanding of the world (Littlejohn \& Foss, 2009: 891). In this study lead to the process of the people in the community of Urantia which constructs its understanding of reality. Reality perceived by thinking Berger and Luckmann was elaborated into some of the thinking that is about the reality in their daily lives that will be individual views about the existence of himself in public or social life, people's views as objective reality and the views of the community as a subjective reality (Berger and Luckmann, 1966) The uniform appearance will assist the reader to read paper of the proceedings. It is therefore suggested to authors to use the example of this file to construct their papers.

This study will not analyze the text content of the book Urantia, although this research theme are associated with the Urantia, because it will examine the events of communication experienced individuals in this Urantia community. Therefore this study focuses only on the personal experiences of community members Urantia formulated in a research title "The Spiritual Communication: Phenomenological Study About The Urantia Community in Indonesia". This study aimed to describe, assess, explore, identify, and analyze more deeply about: a. The interaction among Urantia community members in Indonesia, and $b$. Their understanding of the results of the interaction among Urantia community members in Indonesia.

\section{RESEARCH METHOD}

Based on the characteristics of the Urantia community, researchers feel that the ideal way to unravel this phenomenon is to use a constructivist paradigm and qualitative approach which seeks to understand the symptoms are such and requires sharpness in digging. In doing this research, I use the method of interpretation that are relatively similar to those observed, so that I can enter into the world of the interpretation of people to be the subject of research. In practice, I assume myself as a person who is not part of the observed world, in this case I just cognitively engage with people who observed in this case with members of the community Urantia (Kuswarno, 2009). So it was me since the beginning of the study in 2013 joined the Urantia community of Indonesia.

This study uses a phenomenological tradition, due to unveil the Urantia community members experience, the core of the phenomenological research that reveal the life experiences of individuals. The foundation stone was Edmund Husserl's phenomenological tradition. One is the famous phenomenological thinker Martin Heidegger and Alfred Schulz. In my opinion, to be a member of the Urantia community for research purposes is essential in order to obtain accurate data from observations and interviews with informants. The informants did not feel free to tell all their experience for me to be part of their community.

I got 18 informants who had been members of Urantia Community at least for two years. Then I interviewed them within 2013 till 2016. The interview scripts became a basic or prime data, and completed by observations.

\section{RESUlT AND DISCUSSION}

Based on observations I attended classes on Urantia community, they are taught in order to prepare to return to God in the sacred state like the beginning down to earth. So in this class were taught systematic phases in preparation. Urantia community members are not mutually despise other religions, is actually receiving a wonderful difference in one container. There is no dispute or conflict hot, all you see is a harmonious atmosphere, cheerful, and full of laughter. In addition to interacting verbally (oral and written), the Urantia community members also interact through non-verbal messages and terms are only understood by members of that community alone. For example the way they shake hands when meeting is shaking hands tightly, sometimes patting fellow right palm (toss) them, or hug when they have been met for a long time.

There are some terms that I found when observing their interactions, including the terms Adjuster (True Guru is in the human soul), Love and Light (greeting pronounced the end of sentences) "bodrex" forces (angels or reinforcements derived Lord), Proto (customs), Midwayer (creature who likes to help humans), Guardian angels (pair of guardian angels humans), Morontia (human beings in the world dimension to 5), frequency (electromagnetic waves of the same), Grey (the wishy washy and not clear establishment), love to give (charity), Nebadon (Planet at the center of our system of local government), Michael (Planetary Prince / local leaders of the system), and so forth. 
Based on direct observation, I can understand some of the concepts of their lives resulting from the interactions among the Urantia community members in understanding the values contained in the Urantia book. These concepts include the concept of Time, Person Concept, Concept of Life after Death, the concept Planet and the Universe:

1. The concept of time, according to them there was no time past and future, that there is time now (everytime is Now). This implies that do not get trapped by the past or to repeat the same mistakes of the past (move on), and do not also trapped by wishful thinking ahead makes frequent daydreaming and not working. Do what can be done now do not like to procrastinate.

2. Human concepts, they think all men are brothers because they come from the same source (from the same source). Every human being has the tasks to be accomplished in this world. Humans live in pairs, then they think that gay people were turned away by the energy upset the balance of nature. This relates to the concept of day and night in pairs, and the balance (yin and yang). Man must know his Adjuster to get to know his Lord so that it can partner with God in all his affairs. Man should religion (any religion), because religion is the path to recognition of God. Humans perceive God Almighty, was so great that not enough is presented in one religion (God is too big to fit in one religion).

3. Concept of Life after Death (Life after Death), they think death is the beginning of a long journey into the future, ie through the stages of the learning process of the human soul from one form to form, from one of our ascent to the heavens more until finally reaching heaven (Havona).

4. The concept Planet and Universe, According to them that almost all the planets in our solar system was uninhabited, but is not visible by means of NASA or other space agencies because of the form they are in dimension 5, 6, and so on. Our planet is Earth, which has another name Urantia, the planet's most isolated and heavy mass of three dimensions, so it cannot be connected to the planets that are in another galaxy. Isolation of the planet due to the betrayal of Lucifer followed by the leaders of the other planets, including the leadership of the planet at that time along with his Caligastian forces. At a later time when human spirituality increases then the earth will return shine like it used to be. This universe has seven super large universe (super Universe), in which there are 7,000,000,000,000. Uninhabited planet. Our Earth (Urantia) is located at the Super Universe that 7 th in the area Jerusem on Edentia area that includes the area under the Salvington in power Enza Splandon headquartered in Uversa

The interaction of the Urantia Community with fellow members in the group is established in two circumstances, namely the interaction directly (face to face) in the classroom in a state of learning, and outside the classroom when there is an informal discussion of cross-class mixed together in a community forum Urantia Indonesia. The second condition, when far apart to interact through social media such as WA group, Path, and Facebook.
The interaction of community members Urantia with the outside world is well established, diffuse, and without privileging self. So it is not too different plasticity at all, but will see the difference in their views of life. When they interact with those closest to them and the community, they strive always to bring the benefits wherever they are. In accordance with one of their slogans is "Love and Light", that they do everything with love, look at every human being with love, and become light for those who need lighting. Then the Urantia community members constantly strive always to benefit the environment.

In addition to the interaction with the public, community members Urantia interaction with all beings and the universe was established. This is in accordance with one of the achievements to be achieved by this community that is in sync with the universe. So that their behavior was very awake so as not to damage the environment and the universe, and always provide positive benefits for the environment and the universe through behavior and energy emitted.

Humans interpret the reality of the result of interaction with other human beings, both in the primary group and with society in general. Primary groups are small groups influence each other affection (Reading, 1986: 184). Urantia community, based on the previously described, can be categorized as primary group. This is evident from the cohesiveness in affection (tied strong flavor), which became the capital of their strong solidarity and a tolerant attitude.

The interactions of the Urantia Community with fellow members in the group have resulted in understandings of certain members of the reality. Their communication effectiveness is determined by a sense of closeness that exists among them. These flavors have been the basic essence of the keys to success is effective communication among in their group. So it can be said that any message that will be delivered one individual to the other individuals will be understood effectively when using a sense that the higher frequencies, where the function of spiritual communication. It turned out that the concept is very simple that if you want to achieve effective communication must involve spiritual communication in any form and way of communicating.

Activities of Urantia community member communication has become a key communication effectiveness those who make a close bond between them. When referring to previous exposure of spirituality, the means of communicating Urantia community members are communicating with the involvement of the spiritual dimension. The Energy force a sense of interconnected with each other to make Urantia community is so solid. It makes a unique relationship among the Urantia community members.

\section{CONCLUSION}

Urantia community in Indonesia is a spiritual community that embraces universal values. They get together and discuss the themes contained in the Urantia book (The Urantia Book). Cohesiveness they are bound by common purpose and meaning of life. So that these communities included in the category of primary groups. Based on the results and analysis of this study, it can be concluded that: 
a. Interaction with fellow the Urantia community members, includes two forms of interaction, first, the interaction in the classroom through teaching methods led by a speaker, by way of lectures and question and answer discussion. Secondly, interaction outside the classroom informally meeting and share experiences through social media. Urantia community member interaction with the environment or the world outside the community is done locally by engaging in social activities, and nationally through the works displayed and widely publicized.

b. The process of interaction among the Urantia community members produce new concepts that change the way they communicate. It also affects their understanding of life. Communication experience among the Urantia community members implicated in their communication activities that involve spiritual dimensions. This has been key to the success of their communication to be effective, because everything is delivered with a sense (heart/feeling).

\section{REFERENCES}

[1] Berger, Peter L and Luckmann, Thomas, 1966, The Social Construction of Reality, Penguin Group, England, London.

[2] Bormann E. G, 1983, Symbolic Convergence: Organizational Communication and Culture, dalam L. L. Putnam and M. E. Pacanowsky (Eds.), Communication and Organization: An Interpretive Approach: Beverly Hills, Sage, California.

[3] Creswell, John W. 2009, Qualitative, Quantitative, and Mixed Methods Approachs, Third Edition, Sage Publication. Thousand Oaks California.

[4] Croucher, Stephen M. 2013, Journal of International and Intercultural Communication Vol.6, No.4, 298-316, "Communication Apprehension, Self-Perceived Communication Competence, and Wilingness to Communicate: A French Analysis", (Routledge).

[5] Daniel Mato, 2008, Social Identities Vol. 14, No.3, "Transnational Relations, Culture, Communication and Social Change", (Routledge) London, U.K

[6] DeVito, Joseph A. 1997, Komunikasi Antar Manusia, Profesional Books. Jakarta.

[7] Erla S. Kristjansdottir dan Sara Deturk, 2013, The Howard Journal of Communication, 24:194-211, "Cultural Insiders to Cultural Outsiders: Structure, Identity, and Communication in the Adaptation of Domestic, Involuntary Migrants", Taylor and Francis Group, LLC. U.K.

[8] Hans J. Ladegaard, 2007, Journal of Intercultural Communication Research Vol. 36, No. 2 pp.139-163, "Global Culture-Myth or Reality? Perceptions of "National Cultures" in a Global Corporation", (Routledge) U.K.

[9] Keith E. Dilbeck, James C. McCroskey, Virginia P. Richmond, dan Linda L. McCroskey, 2009, Journal of Intercultural Communication Research Vol.38, No.1, "Self-Perceived Communication Competence in the Thai Culture" (Routledge) London, U.K.

[10] Keith Miller, Flinders University of South Australia, 2014, Qualitative Social Work Vol. 13(6) 828-841, "Respectful Listening and Reflective Communication From The Heart and with The Spirit", (SAGE), U.S.A.

[11] Kerrie Foxwell-Norton dari Griffith University, Australia, 2013, Journal of Media \& Cultural Studies pada Vol. 27, No.2, 267-282, "Communication, Culture, Community and Country: The Lost Seas of Environmental Policy”, (Routledge) U.K.
[12] Kuswarno, Engkus, 2008. Metode Penelitian Komunikasi, Etnografi Komunikasi: suatu pengantar dan contoh penelitiannya, Widya Padjadjaran.

[13] Kuswarno, Engkus. 2009. Fenomenologi (Fenomena Pengemis Kota Bandung). Widya Padjadjaran.

[14] Littlejohn, Stephen W. Karen A. 2009. Foss. Encyclopedia of Communication

[15] Theory, SAGE Publications, Inc. United States Of America.

[16] Mehrabian, Albert, 1967, Nonverbal Communication, Chicago; Aldine Atherton,

[17] USA.

[18] Miller, Katherine, 2002, Communication Theories: Perspectives, Processes,

[19] and Contexts, The McGraw-Hill Companies, Inc. U.S.A

[20] Moleong, Lexy J. 2000, Metodologi Penelitian Kualitatif, Penerbit PT. Remaja Rosdakarya, Bandung.

[21] Mulyana, Deddy, 2007, Metode Penelitian Komunikasi contoh-contoh penelitian kualitatif dengan pendekatan praktis, PT Remaja Rosdakarya, Bandung.

[22] Mulyana, Deddy, 2013, Metodologi Penelitian Kualitatif : Paradigma Baru Ilmu Komunikasi dan Sosial dan Lainnya. Bandung : PT. Remaja Rosdakarya.

[23] Mulyana, Deddy, 1999, Nuansa-Nuansa Komunikasi, PT Remaja Rosdakarya, Bandung.

[24] Mulyana, Deddy, 2001, Ilmu Komunikasi suatu Pengantar, PT Remaja Rosdakarya, Bandung.

[25] Nadine A. Yehya dan Mohan J. Dutta, 2010, Qualitative Health Research 20(6) 845-858, "Health, Religion, and Meaning: A CultureCentered Study of Druze Women", (SAGE), U.S.A.

[26] Nancy F. Burroughs, James C. McCroskey, dan Vicki Marie, 2009, vol 20:3, 230-239, Communication Research Reports, "Relationships of self-perceived Communication Competence and Communication Apprehension with Willingness to Communicate: A Comparison with First and Second Language in Micronesia", (Routledge) London, UK.

[27] Nasution, S. 2002. Metode Research, Bumi Aksara, Jakarta.

[28] Nimmo, Dan, 2005. Political Communication and Public Opinion. Goodyear Publishing Company, California.

[29] Rakhmat, Jalaluddin, 1991, Psikologi Komunikasi, Penerbit, Bandung : PT Remaja Rosdakarya.

[30] Rakhmat, Jalaluddin, 2004, Psikologi Agama, PT. Mizan Pustaka. Bandung.

[31] Reading, Hugo F., 1986, Kamus Ilmu-ilmu Sosial, CV. Rajawali. Jakarta.

[32] Roberts, Tyler T, 2002, Spiritualitas Posreligius, Qalam. Yogyakarta.

[33] Schutz, Alfred, 1972, The Phenomenology of the Social World, London and Edinburg.

[34] Sobur, Alex, 2013, Semiotika Komunikasi. Bandung : PT. Remaja Rosdakarya. Bandung.

[35] Urantia Book, Urantia Foundation, 1955. 533 Diversey Parkway, Chicago, Illinois 60614 U.S.A.

[36] West, Richard and Turner, Lynn H., 2010. Introducing Communication Theory, Analysis and Aplication, Fourth Edition, McGraw-Hill Companies, Inc. New York.

[37] Zhuravlyov, Ignaty V. 2013, Russian Journal of Communication, Vol.1:4, 401, "Communication Behind The Back of Consciousness", (Routledge). G. Eason, B. Noble, and I.N. Sneddon, "On certain integrals of Lipschitz-Hankel type involving products of Bessel functions," Phil. Trans. Roy. Soc. London, vol. A247, pp. 529-551, April 1955 